The Photography of Victorian Scotland 



\section{The Photography of Victorian Scotland}

Roddy Simpson

EDINBURGH

University Press 
(C) Roddy Simpson, 2012

Edinburgh University Press Ltd

22 George Square, Edinburgh EH8 9LF

www.euppublishing.com

Typeset in 10/12 Goudy Old Style by

Servis Filmsetting Ltd, Stockport, Cheshire, and

printed and bound in Great Britain by

CPI Group (UK) Ltd, Croydon CR0 4YY

A CIP record for this book is available from the British Library

ISBN 9780748654611 (hardback)

ISBN 9780748654604 (paperback)

ISBN 9780748654628 (webready PDF)

ISBN 9780748654642 (epub)

ISBN 9780748654635 (Amazon ebook)

The right of Roddy Simpson to be identified as author of this work has been asserted in accordance with the Copyright, Designs and Patents Act 1988.

Published with the support of the Edinburgh University Scholarly Publishing Initiatives Fund. 